\title{
The reflexive turn in French and German-speaking geography in comparison
}

\author{
O. Graefe \\ Department of Geosciences, University of Fribourg, Fribourg, Switzerland \\ Correspondence to: O. Graefe (olivier.graefe@unifr.ch)
}

Received: 12 April 2013 - Accepted: 16 April 2013 - Published: 30 May 2013

\begin{abstract}
The papers presented by Bernard Debarbieux and Ute Wardenga at the symposium on "Les fabriques des 'Géographies' - making Geographies in Europe" and published in this thematic issue both take a historiographical perspective, which at a first glance seems evident. In order to understand how geography is thought about and practiced, the best is to look back on how these thoughts and practices have been respectively established and have evolved in the different national contexts. But at second glance, this historiographical perspective seems revealing regarding the status and the position of geography as an academic discipline. One can hardly imagine a symposium on the "making philosophy" or "making physics" in Europe privileging such a historiographical stance in order to illustrate and understand the differences and commonalities of a discipline in different countries today. Other disciplines might have favoured a dialogue on how a theory or a prominent author is received in order to excavate the differences or commonalities in a particular discipline of different countries. Such dialogues have been organized for example in Sociology with the exchange of approaches on Bourdieu published by Catherine Colliot-Thélène, Étienne François and Gunter Gebauer (2005). Another example and a reference of such dialogues is the famous debate on hermeneutics between Hans-Georg Gadamer and Jacques Derrida in the early 1980s.
\end{abstract}

The emphasis on the history (Debarbieux) and the way to write the history of geography (Wardenga) points out the difficulty of our discipline to position itself in academia, and reveals the crisis to which Wardenga refers to in her paper. As Ute Wardenga pointed out by quoting Jörn Rüsen, "genetical narratives" are part of identity formation processes by "mediating permanence and change to a process of self-definition" (Rüsen, 1987, cited by Wardenga, this issue). Both presented papers expose in different but complementary ways this identity formation of geography as a distinct discipline on the national scale in France (B. Debarbieux) and on a more international scale (U. Wardenga). The first analyses the conceptualization of space, the nation and the national territory by French geographers, while the second reflects upon the internationalization of the historiography of our discipline, meaning the way history is written and not the history itself. The underlying question here is the specificity of geography in Germany or in France and what their relationships are with other geographies, i.e. in how far they are influenced by or reject ideas and methodologies especially (but not exclusively) from Anglophone geographers.

\section{Two or more geographies in France and Germany?}

While Bernard Debarbieux makes explicit reference to geography in France, Ute Wardenga looks at the international connections and networks of geographers working on the historiography of the discipline, drawing upon numerous references from English, French and German-speaking scholars. Two motions can be distinguished in the presentations of geography in France and the historiography of geography. B. Debarbieux depicts a kind of retreat of Geographers in France, after a phase of universality of geographical thought in terms of concepts and approaches on spatiality and territorialities also present in Germany and in the United States (p. 7) at the turn of the 19th century. With the Vidalian school from the 1920s 
onwards, a French school emerged "eager to cultivate their own personnalité in the field of academic geography, deliberately distancing themselves from German geographers and promoting a French way of doing geography" (Debarbieux, p. 9, this issue). This inward-looking perspective is confirmed by M.-C. Robic's description of the role Ratzel played in France, first seen as a scholarly hero turning into an antifigure and adversary (Wardenga). This differentiation and increasing marginalization, and what M. Houssay-Holzschuh might name provincialisation (this issue) continued, despite some renewal of academic paradigms and methodologies in French geography. Wardenga's article, however, puts a question mark on this appraisal in the specific field of historiography of geography, as she refutes the very idea of national schools, including a French one. She even emphasizes astonishingly that there are no national traditions in writing the history of geography as a result of the theoretical and methodological cosmopolitanization. The exchanges and relationships are perhaps the result of the small size of this group of geographers working on commonly defined issues and research questions, coordinated by a commission of the IGU and above all referring to a common epistemological basis in the form of Kuhn's theory of the structure of scientific revolutions. In comparison with the appraisals of B. Debarbieux and M. Houssay-Holzschuh in this issue, but also accounts of Juliet Fall (2007) or Paul Claval (2003, 2007), geography in France is presented as less connected and underexposed to the international debate. In Germany in contrast, geography is progressively international (cf. Belina et al., 2009) and it imports - at a seemingly increasing speed - approaches from the Anglo-American episteme, following the turns, from the quantitative to the behavioural, from the linguistic and cultural back to the material, from the praxeological to the non-representational and the emotional turn. Nevertheless, the imports of approaches often lag behind and German geographers rarely participate actively in the scientific debates or make any substantial contribution to it. Following a discussion on the list of critical geography in January 2012 (on parroting Deleuze and other French philosophers in geography), one might even call these German imports from the Anglo-American debates a "parroting the parrots", with all the distortions this entails (from French to English to German). The retreat of French and the attempts of internationalization of German geography expose two different answers to the growing entanglements of geography in distinctive ways, as U. Wardenga points out prominently in her conclusion.

\section{The individuation of geography against what?}

Both papers present what Debarbieux calls the individuation of geography as an academic discipline, and what Ute Wardenga frames as identity claims, or a self-affirmation. As individuation and identification processes are to be seen in re- lation to other entities and can be understood as a play of positions and positioning, a Bourdieusian perspective might be helpful to understand these processes. The question is here against what or whom this individuation, identity claims or positioning take place. What power relationships are most relevant in these processes, and to which academic field does this play of positions and positioning refer to? Neither author addresses this extensively, even if $U$. Wardenga refers to "politics of the discipline". If we look at the scholarly fields in which the discipline of geography is located, we find marked differences between the two countries: the prime reference for geography in France are clearly the humanities and social sciences, while the situation is more complicated in Germany. Established institutionally in faculties of natural sciences, in Germany, human geography had very little interface with other social sciences or the humanities. The reference is rather Anglo-American geography, at least since the late 1960s and the focus on spatial analysis. The respective university structures and epistemological paradigms couldn't be more different: in France it is highly centralised, strongly regulated (cf. Debarbieux, Houssay-Holzschuh in this issue), remains in a universalist and encyclopaedist vision of geography, pursues a Cartesian and non-critical Rationalism and favours strong inductive, empiricist research (Bourdieu, 1984:46). Intellectual value - in the sense of reflexivity and participation in intellectual debates - is of less importance in geography than institutional authority, as a geographer emphasized in an interview with Bourdieu (1984:114). The marginalization of geographers who do not adhere to the paradigm of what Debarbieux calls the "orthodox geography" testifies to the purification mechanisms at work in the disciplinary discourse put in place since the beginning of the 20th century.

This approach rarely leads to theoretical debates and lacks innovation and creativity (Fall, 2007). In addition, geography is located at the very bottom of the French academic hierarchy, as Bourdieu pointed out repeatedly in his book about the French academic system $(1984: 144,182)$. From this perspective, the power relationships are highly asymmetric and geography is in a weak position to compete with other disciplines of the humanities, like sociology, history, social anthropology or cultural studies, not to mention philosophy. This position explains at least partially the relationship of French geographers with colleagues of neighbouring disciplines and their lack of openness necessary for intellectual, conceptual or theoretical cross-fertilization. French geographer Paul Claval confirms the ambivalent relationship with the humanities in a mixture of regret and justification of the position of geography. The humanities are both a point of reference and one of differentiation.

"Les géographes français n'adhèrent généralement pas aux formes d'approche critique qui se sont épanouies dans le monde anglo-saxon parce qu'elles noient leur discipline 
dans le magma confus de disciplines de la culture. Qu'est-ce qui différencie le géographe du littéraire ou de l'ethnologue à partir de l'instant où les uns et les autres ne s'intéressent qu'aux textes et aux illustrations qui les accompagnent?" (Claval, 2003:107)

German and Anglo-American geography are no longer the entity against which the identity claims are addressed, as it was the case at the beginning of the 20th century. The individuation process of French geography is oriented towards neighbouring disciplines. The lines of demarcation that Debarbieux mentions in his article shifted from being drawn against German geography to lines to distinguish geography from neighbouring disciplines in France.

This individuation in form of a repli sur soi or isolation produced a decline criticized by Fall (2007), Debarbieux and by Houssay-Holzschuh (this issue) and was even acknowledged by Claval (2007:266):

"Un déclin s'esquisse dans les années 1950: les géographes ont conscience de l'inefficacité des deux outils qui ont fait leur succès, l'analyse des genres de vie et les études régionales, mais sont incapables de les remplacer. Ils ne prennent qu'avec retard le tournant de la nouvelle géographie, et n'en incorporent pas tous les éléments. [...]

La géographie française souffre des retards qu'une partie de ceux qui la pratiquent ont pris, de la réticence avec laquelle ils s'expriment en anglais et de leur hésitation à participer, de ce fait, aux rencontres internationales."

The individuation of German-speaking geography seems to have taken different forms, which could be summarized as a dialectic of internationalization and cluster building, i.e. the formation of strong cliques of geographers structuring the disciplinary field. Unable to go in depth here, the internationalization has been vividly debated in Germany with a focus on the import of ideas into the Neue Kulturgeographie. For critical geographers this internationalization led to an inclusion of critical voices in a field dominated until recently by traditional geography (Belina et al., 2009). This opening up and exposure of geography in Germany comes along with internal network formation, or what Steinbrink and a group of young scholars named cliques (2010). Whether there is a link between both processes remains open, but their network analysis show impressively how a small number of geographers are in a central position of the field and able to define research agendas and approaches. Very controversial, the study has been republished in the Berichte zur deutschen Landeskunde in 2012 (Vol. 86, no. 4) and has been discussed extensively by colleagues (B. Korf, A. Schlottmann, P. Goeke, K. Arzheimer a.o.). A new culture of critical debate about the field and self-reflexive positionality seems to take pace in Germanspeaking geography.
Both papers presented by Ute Wardenga and Bernard Debarbieux give interesting insight and impressions of how geography has evolved recently: dynamic, open and able to participate in the academic debates by following new paradigms of historiography on one side, and remaining isolated and confined in "national way of thinking and doing" on the other, a context which seems far off to encourage exchange, dialogue or cross-fertilization across linguistic and epistemic boundaries.

\section{The difficult dialogue across language and epistemic boundaries}

Wardenga's article exemplifies very well the conditions necessary for the establishment of a dialogue across language barriers, despite specific identity claims. First there is the common methodological ground, initially the biographical paradigm, which was soon replaced by a Kuhnian approach in geography history writing. Secondly, a strong and wellrecognized institution in the form of the IGU commission of "History of Geographical Thought" contributed to the structuring of the field by establishing a research agenda via an ambitious publication programme. And thirdly, there is an interdisciplinary curiosity enabling the import of ideas and approaches from the ongoing debates in the History of Science and Science studies. This special epistemic common ground seems even more relevant considering language differences can hide differences in logics. Following an argument of Wismann (2012), speaking and understanding a language is not equivalent to understanding the thoughts and logics expressed. Every polyglot geographer understands that space - Raum - espace are not semantically equivalent in meaning, while the translation is formally correct. The same applies for other famous examples like mind - Geist - esprit or knowledge - Kenntnis - connaissance. Wismann tells an anecdote of Humboldt trying in 1798 to explain Kantian philosophy to French Philosophers in Paris, where he stayed $25 \mathrm{yr}$. After $7 \mathrm{~h}$ of lecturing, he encountered a complete lack of understanding. While the words were correct, the logic expressed in the syntactic structure was not understood. "Le français résistait à ce que Humboldt voulait lui faire dire, à partir de la pensée kantienne élaborée en allemand" (Wismann, 2012:15). In other terms, some ideas travel across language barriers better than others. One example is N. Luhmann's system theory, hardly reviewed and referred to in French or Anglo-American geography, while it is used as a theoretical framework of a dynamic and productive group of German geographers like M. Redepenning, R. Lippuner, A. Pott, or P. Goeke to name a few. Another example is the rather discrete presence of B. Latour in French geography because of the dominance of Cartesian rationalism, while his work is highly regarded in geography outside France, including French-speaking Switzerland. 
Theories can be defined as specific languages as evidenced by the flood of theory dictionaries, glossaries or lexicons that are published on theory giants, such as Luhmann, Foucault or Bourdieu. Ute Wardenga and Bernard Debarbieux show in their specific ways how paradigmatic and theoretical borders fluctuate, open and close in relationship with the fieldinternal play of positions and positioning. The scientific dialogue across differences of language seems far easier inside the same paradigm than between different paradigms within the same linguistic community. In this sense, semantics are more relevant than words.

We cannot escape the challenge in mapping European geographies. How can we grasp, differentiate and delineate geographies beyond the differences in languages and above all without reifying at the same time the national referential like French or German school or even "Frenchness", "Germanness" or any other essentialising "ness" in geographical thought?

Edited by: B. Korf

Reviewed by: one anonymous referee

\section{References}

Belina, B., Best, U., and Naumann, M.: Critical geography in Germany: from exclusion to inclusion via internationalisation, Soc. Geogr., 4, 47-58, doi:10.5194/sg-4-47-2009, 2009.

Bourdieu, P.: Homo Academicus, Les editions de Minuit, Paris, France, 1984.

Claval, P.: Causalité et géographie, L'Harmattan, Paris, France, 2003.

Claval P.: Epistémologie de la géographie, Armand Colin, Paris, France, 2007.

Colliot-Thélène, C., François, E., and Gebauer, G. (Eds.): Pierre Bourdieu: deutsch-französische Perspektiven, Suhrkamp, Frankfurt, Germany, 2005.

Fall, J.: Lost geographers: power games and the circulation of ideas within Francophone political geographies, Prog. Hum. Geogr., 31, 195-216, 2007.

Wismann, H.: Penser entre les langues, Albin Michel, Paris, France, 2012. 